\title{
Serological survey of anti-Salmonella antibodies in coatis (Nasua narica) and raccoons (Procyon lotor) in southeast Mexico
}

\author{
Monitoreo serológico de anticuerpos anti-Salmonella en coatíes (Nasua narica) \\ y mapaches (Procyon lotor) en el sureste de México
JL de-la-Rosa-Arana ${ }^{a}$, CI Muñoz-García ${ }^{b}$, VH Godínez-García ${ }^{a}$ C Villanueva-García ${ }^{c}$, LM Gama-Campilloc ${ }^{c}$ A Almanza-González ${ }^{a}$, E Rendón-Franco ${ }^{b^{*}}$

\begin{abstract}
Infectious diseases are important threats for the conservation of wild carnivores, particularly when these animals are in close proximity to humans and domestic animals. However, available data regarding zoonotic infectious diseases in wild carnivores in tropical areas are scarce. The aim of this work was to perform a serological survey of Salmonella and other zoonotic bacteria in coatis (Nasua narica) and raccoons (Procyon lotor) from a semi-urban tropical environment. Coatis and raccoons were trapped and chemically restrained between 2009 and 2011. A total of 100 serum samples, 44 from coatis and 56 from raccoons, were analysed. Antibodies were determined using a commercial agglutination kit (Febriclin®), and antigens "O" and "H" of Salmonella typhi, S. paratyphi "A", Brucella abortus and Proteus OX-19 were analysed. Antibodies against Salmonella typhi were found but not against the other bacteria. The general seroprevalence for Salmonella typhi antibodies was $63.6 \%$ for coatis and $67.9 \%$ for raccoons. Titers for both species ranged from 1:20 to 1:80. Antibodies to the "O" antigen were more prevalent (59.1\% for coatis and $62.5 \%$ for raccoons) than those for the "H" antigen (36.4\% for coatis and 50\% for raccoons). Seroconversion and a loss of antibodies were detected. The results suggest that both procyonid populations had a high contact rate with Salmonella, although at a low titer level, but there was no evidence of contact with other zoonotic bacteria.
\end{abstract}

Key words: Brucella abortus, carnivores, procyonid, Rickettsia.

RESUMEN. Las enfermedades infecciosas son un riesgo para la conservación de carnívoros silvestres, particularmente cuando la fauna silvestre está en estrecho contacto con humanos y animales domésticos. Pese a lo anterior, información relacionada con enfermedades zoonóticas en carnívoros silvestres es escasa, particularmente en áreas tropicales. El objetivo del presente estudio fue realizar un monitoreo serológico de Salmonella y otras bacterias zoonóticas en coatíes (Nasua narica) y mapaches (Procyon lotor) en un ambiente semiurbano. Coatíes y mapaches fueron capturados y contenidos químicamente desde 2009 a 2011. 100 muestras de suero, 44 de coatíes y 56 de mapaches, fueron analizadas. Los anticuerpos fueron determinados usando una prueba comercial de aglutinación (Febriclin $\left.{ }^{\circledR}\right)$, los antígenos "O" y "H" de Salmonella typhi, S. paratyphi "A", Brucella abortus y Proteus OX-19. Anticuerpos contra Salmonella typhi fueron detectados, pero no contra otras bacterias. La seroprevalencia general de Salmonella typhi fue 63,6\% para coatíes y 67,9\% para mapaches. Los títulos para ambas especies fue de 1:20 a 1:80. Anticuerpos contra el antígeno "O" fueron más prevalentes $(59,1 \%$ para coatíes y $62,5 \%$ para mapaches) que para el antígeno " $\mathrm{H}$ " (36,4\% para coatíes y $50 \%$ para mapaches). Seroconversión y pérdida de anticuerpos fueron detectados. Los resultados muestran que ambas poblaciones de prociónidos tienen una alta tasa de contacto con Salmonella, aunque con títulos bajos, sin embargo no se encontró evidencia de contacto con otras bacterias zoonóticas.

Palabras clave: Brucella abortus, carnívoros, prociónido, Rickettsia.

\section{INTRODUCTION}

Procyonidae is a New World family of the Carnivora order that includes raccoons (Procyon spp.) and coatis (Nasua spp.). Procyonids inhabit a wide range of semi-urban, rural and wild environments and are generally omnivorous (Lotze and Anderson 1979, Gompper 1995). In Mexico,

\footnotetext{
Accepted: 24.03.2016.

anstituto de Diagnóstico y Referencia Epidemiológicos, Secretaria de Salud, México D. F., México.

bUniversidad Autónoma Metropolitana, Unidad Xochimilco. Departamento de Producción Agrícola y Animal, México D. F., México.

'Universidad Juárez Autónoma de Tabasco, División Académica de Ciencias Biológicas, Villahermosa Centro, México.

*Corresponding author: E Rendón-Franco; Calzada del Hueso 1100, Colonia Villa Quietud, Coyoacan, México D. F., 04960; emilio.rendon. franco@gmail.com
}

seven species of Procyonidae have been recorded, and two of them, the white-nose coati (Nasua narica) and the raccoon (Procyon lotor), are widely distributed across the country. These species gather in large groups, show a high degree of sociality and live in close proximity to human settlements, such as tourist parks and livestock areas. Both species are legal and illegally hunted and are frequently eaten by local communities (Contreras-Moreno et al 2012). The above-mentioned factors could favor pathogen transmission between humans, domestic animals and wild procyonids because high intra- and inter-species contact exists.

Racoon is an abundant wild carnivore in the USA (United States of America) and has been introduced to the European continent. As some reports have shown, it can act as vector and reservoir of many zoonotic pathogens, such as rabies and Salmonella (Beltrán-Beck et al 2012). However, most of these studies were performed 
in hunted animals (Bigler et al 1975, Morse et al 1983). Studies in raccoons have shown an increased prevalence of infection with pathogens when characteristics such as social flexibility, large group sizes and animal aggregation caused by anthropogenic resource availability are present (Wright and Gompper 2005). White-nose coatis are distributed from southern USA to northern South America (Gompper 1995), and although the biological features of white-nosed coati are well-known, its interactions with pathogens have been scarcely studied.

Currently, wild carnivores face serious conservation problems; infectious diseases are one of the main threats (Funk and Fiorello 2001). Animal clusters and high contact rates with humans and/or domestic animals were linked to increase the prevalence of pathogens (Packer et al 1999). Certain infectious diseases, such as Salmonella, are commonly shared between humans, domestic animals and wildlife. Salmonella, a gram-negative enterobacteria, is one of the most studied pathogens in wildlife. This bacterium induces enteric diseases in animals and humans. It has been recorded as a cause of mortality in an endangered American wild felid and also as a cause of massive mortality in wild birds (Hall and Saito 2008, Silva-Hidalgo et al 2012). However, there is no evidence of its role in carnivores. Some authors have proposed wildlife as reservoirs of Salmonella, facilitating the transmission to domestic animals and humans. Other bacterial infections, such as Brucella, Leptospira, Mycobacterium and Rickettsia have been reported in carnivores and are also suggested to be a threat to wildlife conservation (Murray et al 1999).

Because information on the prevalence of microorganisms in Procyonids is scarce, increased knowledge on "wildlife pathogens" in this group can help to establish the impact of the pathogens on veterinary and human health as well as on wild animal health. Thus, the aim of this work was to perform a serological survey of Salmonella and other zoonotic bacteria in coatis and raccoons from a semi-urban environment.

\section{MATERIAL AND METHODS}

\section{AREA OF STUDY AND ANIMAL POPULATION}

The study was carried out at the archaeological museum and park "Parque-Museo de la Venta" located in Villahermosa City, Tabasco State, Mexico (18 00' 05.39"' $\mathrm{N} 92^{\circ} 56^{\prime} 02.52^{\prime} \mathrm{O}, 17 \mathrm{masl}$ ). The area is characterised by a humid and tropical climate with a temperature range from 17.3 to $42.5^{\circ} \mathrm{C}$, a relative humidity of $80 \%$ and an average rainfall of over 2,000 to 4,000 mm per year. The park has a secondary growth forest of 4.3 hectares. This is a green area completely surrounded by a lagoon and human settlement. Both procyonid populations live inside the park and forage on regional natural resources and food from tourists. Additionally, coatis are supplemented by the park service personnel with fruit, oats, bread and hardboiled eggs. The abundance of the procyonid populations during the time in which the study was conducted was 98 \pm 26 (standard error (SE)) individuals for raccoons and $108 \pm 8$ SE for coatis. Abundance was determined through a capture-recapture method (Lincoln-Petersen algorithm) with R-capture $®$ ver. 3.0.1 software. Contact with domestic animals is limited but not impossible, particularly with free roaming feral cats, because there are no barriers limiting the access to the park.

\section{ANIMAL TRAPPING}

Animals were handled according to the American Society of Mammalogists recommendations (Gannon et al 2007) with the permission of the Mexican Ministry of Environment and Natural Resources (Registration FAUT-0250), and the handling protocol was approved by the Bioethics Committee of the Universidad Autónoma Metropolitana (DCBS.CICUAL.008.13). Serum samples were obtained between 2009 and 2011. Raccoon trapping was performed on ten consecutive nights during each period with box traps (No. 108, Tomahawk Live Trap Company, Hazelhurst WI, USA). Coatis were captured by sedation with a dart shot using a blowgun at 2 to 4 meters away from the animal. Chemical restraints were performed with 40 to $100 \mathrm{mg} /$ individual of ketamine chlorohydrate (Pisa-Agropecuaria, Guadalajara, JAL, Mx) and 2 to $4 \mathrm{mg}$ / individual xylazine (Pisa-Agropecuaria, Guadalajara, JAL, $\mathrm{Mx})$. The average weight of coatis was $3.60 \pm 0.7 \mathrm{~kg}$ and that of raccoons was $4.75 \pm 1.2 \mathrm{~kg}$. While animals were sedated, data regarding sex and age were recorded, and a $5 \mathrm{~mL}$ blood sample was taken from the jugular vein. All animals were clinically healthy. Starting in 2010, each animal was tattooed with a consecutive number and then released. Because tattoos were not performed in 2009, those samples were only considered for the presence of antibodies but not for the recapture analysis. Blood samples were centrifuged at 1,500 revolutions per minute for 10 minutes and sera were separated and frozen at $-20{ }^{\circ} \mathrm{C}$ until lab analyses were performed.

\section{AGGLUTINATION TEST TO BACTERIA}

A commercial test to detect antibodies to bacteria was used (Febriclin $®$, Ciudad de México, DF, Mx). A total of 100 serum samples, 44 from coatis and 56 from raccoons, were analysed. The Febriclin ${ }^{\circledR}$ test contains the following antigens: Salmonella Paratyphi "A", Brucella abortus, Salmonella Typhi "O" and "H" antigens and Proteus OX-19 was included because of its cross reactions with Rickettsia spp. Serial serum dilutions from 1:20 to 1:320 were mixed with each antigen $(0.013 \mathrm{~mL}$ for each antigen $)$ and placed on a plate. All samples were analyzed in duplicate. The plate was shaken for 2 minutes and observed for agglutination using indirect light against a dark background. 


\section{STATISTICAL ANALYSIS}

Antibody prevalence was calculated independently for each studied bacteria. In particular, the Salmonella Typhi antibodies were carefully analyzed because of their independent reactivities to the " $\mathrm{O}$ " and " $\mathrm{H}$ " antigens. In addition, an extra analysis was performed considering both antigens simultaneously. Serum samples were considered positive at a dilution of 1:20, and samples were considered positive for Salmonella thypi if the sample was positive for antigen "O" or " $\mathrm{H}$ ". Analysis included a description of the following factors: species, age, and sex. Comparisons among groups were performed by two-tailed chi-square tests using OpenEpi $3.03{ }^{\circledR}$ program $^{1}$.

\section{RESULTS}

Antibodies to Salmonella Typhi antigens were detected but not to S. Paratyphi "A", Brucella abortus or Proteus OX-19 antigens. The general prevalence (positive to "O" or " $\mathrm{H}$ " antigens) was $63.6 \%$ for coatis and $67.9 \%$ for raccoons. For coatis, the prevalence for the "O" antigen was $59.1 \%$, and it was $36.4 \%$ for the " $\mathrm{H}$ " antigen. In raccoons, the prevalence of the "O" antigen was $62.5 \%$, and it was $50 \%$ for the " $\mathrm{H}$ " antigen. The prevalence of both antigens ("O" and "H"antigens) was $31.8 \%$ for coatis and $46.4 \%$ for raccoons. Table 1 summarises the distribution of serum samples and the prevalence related to sex and age. No differences were detected $(\mathrm{P}>0.05$; two-tailed chi-square test) in the prevalence of either antigen ("O" or " $\mathrm{H}$ ") in relation to species, age or sex.

The range of antibody titers for each antigen in both species was 1:20 to $1: 80$. For coatis, the mean antibody titer to antigen " $\mathrm{H}$ " was 1:32.5 and for antigen "O" it was $1: 30$. For raccoons, the mean antibody titer to antigen " $H$ " was $1: 27.8$ and for antigen "O" it was $1: 37$. The distribution of titers is presented in table 2 .

During the study, two coatis and four raccoons were recaptured. The two coatis were captured in the winter of 2010 and again in the winter of 2011. One individual was negative on both occasions, and the other had a 1:40 titer for the " $\mathrm{H}$ " antigen and a 1:20 titer for the "O" antigen at the first capture and was negative for both antigens at recapture. For raccoons, two animals were first captured in the summer of 2011 and later recaptured in the winter of 2011. Both were negative when first caught and positive at recapture. One of them had 1:20 titers for both antigens and the other had a 1:40 titer for just the "O" antigen. The other two raccoons were captured three times between the summer of 2010 and the summer of 2011. One animal was negative for the " $\mathrm{H}$ " antigen at all captures and was negative for the "O" antigen at the first and third captures

1 Dean AG, KM Sullivan, MM Soe. 2014. OpenEpi: Open Source Epidemiologic Statistics for Public Health, Versión 303. http://www. OpenEpi.com; Accessed 13/01/2015
Table 1. Serological monitoring to Salmonella Typhi " $\mathrm{H}$ " and "O" antigens in procyonids. Values represent the number of individuals and values in parentheses are percentages.

Monitoreo serológico de antígenos "H" y "O" de Salmonella Typhi en procionidos. Los valores representan individuos y los valores entre paréntesis el porcentaje.

\begin{tabular}{lcccc}
\hline & $\mathrm{n}$ & $\mathrm{O}$ or $\mathrm{H}$ & $\mathrm{O}$ & $\mathrm{H}$ \\
\hline Coati & 44 & $28(63.6)$ & $26(59.1)$ & $16(36.4)$ \\
Raccoon & 56 & $38(67.9)$ & $35(62.5)$ & $28(50.0)$ \\
& & & Coati & \\
Male & 26 & $19(73.1)$ & $19(73.1)$ & $11(42.3)$ \\
Female & 17 & $8(47.1)$ & $7(41.2)$ & $5(29.4)$ \\
Adult & 38 & $24(63.2)$ & $22(57.9)$ & $15(39.5)$ \\
Young & 6 & $4(66.7)$ & $4(66.7)$ & $1(16.7)$ \\
& & & Raccoon & \\
Male & 23 & $16(69.6)$ & $16(69.6)$ & $12(52.2)$ \\
Female & 31 & $20(64.5)$ & $17(54.8)$ & $15(48.4)$ \\
Adult & 41 & $26(63.4)$ & $24(58.5)$ & $20(48.8)$ \\
Young & 12 & $9(75.0)$ & $8(66.7)$ & $6(50.0)$ \\
\hline
\end{tabular}

Table 2. Titer distribution of Salmonella Typhi antigen "H" and "O". Values represent the number of animals positive at a specific titer. The values on the left are for antigen " $\mathrm{H}$ " and the values on the right are for antigen "O".

Distribución de títulos contra antígenos "H" y "O" de Salmonella Typhi. Los valores representan número de animales positivos a un título específicos. Valores a la izquierda son para antígeno " $\mathrm{H}$ " y valores a la derecha son para antígeno "O".

\begin{tabular}{lcccc}
\hline & \multicolumn{4}{c}{ Titer H/O } \\
\cline { 2 - 5 } & 0 & $1: 20$ & $1: 40$ & $1: 80$ \\
\hline Raccoon & $28 / 21$ & $19 / 17$ & $8 / 12$ & $1 / 6$ \\
Coati & $28 / 18$ & $10 / 15$ & $4 / 10$ & $2 / 1$ \\
\hline
\end{tabular}

but positive (1:20 titer) at the second capture. The second animal was captured between the winter of 2010 and the winter of 2011. This animal was positive all three times for both antigens (first capture, 1:40 and 1:20; second capture, $1: 20$ and 1:20; third capture 1:20 and 1:40 titers for antigens " $\mathrm{H}$ " and "O", respectively).

\section{DISCUSSION}

The present study found a high prevalence ( $>60 \%$ ) of antibodies to Salmonella antigens in coatis and raccoons living in southeastern Mexico. Because data regarding the prevalence of infectious diseases in procyonids are scarce, this new information relating to the main zoonotic bacteria found in these species is important. Little is known about the true prevalence of Salmonella in wild animal populations from tropical areas, and its estimation via serodiagnosis is a promising and cost-effective monitoring method compared to the more complicated and costly isolation techniques. 
This estimation method has also been successfully tested in human populations to appraise and compare the prevalence and incidence of Salmonella (Falkenhorst et al 2012). However, it is important to corroborate this finding with other techniques such as molecular or isolation analyses, to verify the accuracy of the serodiagnosis for each species.

Isolation of Salmonella has been conducted in raccoons from USA and Canada (Compton et al 2008, Jardine et al 2011). However, there are no published data on the occurrence of Salmonella in coatis. Our study found that the prevalence was $63.6 \%$ for coatis and $67.9 \%$ for raccoons. These values are higher than those found in previous Salmonella studies, which reported a range of prevalence from 7.4 to $27 \%$ in bacteria isolated from animals trapped near urban areas of Pennsylvania and Florida (Bigler et al 1975, Compton et al 2008). One possible explanation for these differences in prevalence could be differences in the sensitivities of different laboratory diagnostic methods, as has been observed in dogs in which isolation techniques were less sensitive than serological tests (Fukata et al 2002). However, this should be validated for raccoons and coatis. Antibodies to the "O" and " $\mathrm{H}$ " antigens of Salmonella typhi were detected in this study. However, because the studied serotypes are commonly associated with human microbiota, the bacteria infecting both populations may belong to Typhi serotype or a combination of other serotypes as it is not clear how many Salmonella serotypes exist. If this is the case, the presence of members of serogroup "D", which are related to Salmonella Typhi (i.e. Enteritidis, Gallinarum, Pullorum or Dublin) is a strong possibility. This should be further studied (Thorns et al 1992) because previous studies of raccoon populations have shown the presence of multiple Salmonella D serotypes (Jardine et al 2011).

Differences between species or sex were not detected, which is similar to results reported by Jardine and collaborators (2011) for Canadian raccoons. In addition, we did not find differences between age groups. Verma and collaborators (2008) found that the prevalence in dogs increased with age. Further studies with additional samples will be required to determine if there are differences between age groups. However, differences between the prevalence of antigens were found. Independent analysis of the prevalence for antigens revealed that antigen " $O$ " was more prevalent than antigen " $\mathrm{H}$ ". This is similar to the tendency observed by Verma and collaborators (2008) in dogs. A higher prevalence of antigen " $O$ " has been attributed to the earlier appearance of the antibody against this somatic antigen in relation to the appearance of antibodies against the flagellar antigen " $\mathrm{H}$ ", which appear later. Antibodies against antigen "O" are also attributed to acute infections (Olopoenia and King 2000). There are no previous reports about antibody titers in procyonids. In dogs, titers have been reported from 1:20 to 1:2560 for antigen " $H$ " and "O". Seventy-five percent of dogs positive for the "O" antigen and 59\% positive for " $\mathrm{H}$ " had titers between 1:20 and 1:80 (Verma et al 2008). Low titers among procyonids and dogs could be related to an inactive infection.

In the case of the six procyonids recaptured, a follow-up analysis of antibodies was performed. In both recaptured coatis, antibodies were not detected after a year. This result suggests a short duration for the antibodies. The animals were caught in the winter of 2010 and again 12 months later, but were not captured in between these two dates, so the duration of the antibodies could be even shorter than this time period. A raccoon was captured three times and had seroconverted just for antigen "O" (1:20) at the second capture. It was negative six months later. In both species antibodies were no longer detected. No reports exist about antibody dynamics in wild carnivores under natural conditions. However, Junge et al (2007) showed that raccoons became negative to canine distemper, feline parvovirus, canine adenovirus and Leptospira interrogans, but, they also found that some animals kept their antibodies during the entire study. One raccoon was positive during all three captures, however, the titers for antigen " $\mathrm{H}$ " decreased and titers for antigen "O" increased. This long-term antibody could be associated with reinfections. Jardine et al (2011) have reported on the monthly recapture of raccoons over a period of five months and showed the presence of infection, then no infection and then a reinfection with the same or different serotypes. These facts, plus the short persistence of antibodies against Salmonella, could explain the lack of detectable antibodies between captures as well as their persistence for a long time.

The source of Salmonella infection in procyonids cannot be easily distinguished. However, it is well known that poor-quality anthropogenic food obtained by scavenging on garbage or from tourists could enhance pathogen transmission (Becker et al 2015). Scavenging and consumption of food offered by tourist are behaviors observed by authors (CIMG, CVG and ERF) in procyonids from the studied area. Another possible source of infection could be the polluted water from the surrounding lagoon because animals have free access to this water, and a recent report describes the presence of another zoonotic bacterium, Leptospira interrogans, in resident Antillean manatees (Trichechus manatus) from the same landlocked lagoon (Aragón-Martínez et al 2014). Finally, the high pattern of Salmonella seroprevalence observed indicates an elevated proportion of subclinical infections in coatis and raccoons, a tendency previously demonstrated in human populations (Falkenhorst et al 2012). Thus, the presence of Salmonella in semi-urban wildlife could represent a serious threat to both humans and wildlife, and both sides of this issue need to be addressed: 1) Procyonids from this tourist park might represent a potential source of human infection because animals can act as asymptomatic carriers. Some studies show that a high prevalence of Salmonella in wild populations, as the presented here, correspond to human outbreaks in the same region, potentially indicating an epidemiological link (Hoelzer et al 2011); 2) the presence 
of Salmonella in wild carnivores might represents a serious conservation issue because fatal illness could occur, such as the outbreaks recorded recently in a wild artic fox (Alopex lagopus) and a captive ocelot (Leopardus pardalis). In the former case, Salmonella Enteritidis was a secondary pathogen associated to Toxoplasma gondii, which can contribute to the severity of pathological findings (acute liver necrosis, intussusception in the caudal jejunum, dehydration, splenic focal necrosis and fecal inconsistency) and consequently cause death (Sørensen et al 2005). In the latter case, the primary cause of the ocelot's death was a severe haemorrhagic enterocolitis and severe nephritis associated with the presence of the Salmonella enterica serovar Albany (Silva-Hidalgo et al 2012).

All animals studied were negative for Brucella and Proteus antigens. Antibodies against B. abortus have been reported in raccoons living in close proximity to infected livestock (Boeer et al 1980, Schnurrenberger et al 1985), and antibodies against B. abortus and B. canis have been reported in captive South American coati (Nasua nasua; Oliveira-Filho et al 2012). In our study, no reactivity was detected to Brucella antigens. This may be because the animals live inside the city and have no contact with livestock, although Brucella has been reported in local cattle ${ }^{2}$. Proteus is mainly used as diagnostic test for Rickettsia because a cross-reaction exists. Rickettsia has been reported in raccoons from the US and Japan (Alexander et al 1972, Baba et al 2013) and in humans from the northern and southeastern regions of Mexico (Zavala-Castro et al 2006). Rickettsial infections were associated with tick bites, but in the present study antibodies against Proteus were not detected. The absence of Rickettsia may be explained by the absence of ticks. This assumption is supported by a parallel study focused on the description of ectoparasites in both procyonid populations during the same time period, which did not find ticks in these populations (Issak-Delgado 2014). Thus, there is a need to study the abiotic and biotic factors to understand the transmission of Brucella and Proteus (Rickettsia) between wild and domestic animals and the role of arthropods.

Studies of Salmonella in raccoons from USA and coatis from South American do exist. However, to the best of our knowledge, this is the first report of antibodies against bacteria in white-nose coatis and raccoons in their tropical populations. The results suggest that both populations had contact with Salmonella. Increasing our knowledge about the role of bacteria in procyonid health is important. More studies are necessary to isolate and identify the species of bacteria that actually infect both populations and the risks of illness. In addition, it is imperative to determine the role of coatis and raccoons as reservoirs of etiological agents that may have an impact on public and veterinary health.

2 SENASICA, Servicio Nacional de Sanidad, Inocuidad y Calidad Agroalimentaria. 2013. Zoosanitary weekly reports. http://www. senasica.gob.mx/?id=2761; Accessed 2015/01/23

\section{ACKNOWLEDGEMENTS}

We would like to thank María Teresa Corona-Souza and Rita Iliana Terán-Toledo for technical support and Irma Valle and Martín Piñon for taking care of the animals at the InDRE facilities. We would also like to thank the authorities and staff of the Archaeological Museum and Park "La Venta" at Tabasco, México, for all their support. Jorge Luis de la Rosa-Arana is a SNI-CONACyT, Mx fellow.

\section{REFERENCES}

Alexander AD, V Flyger, YF Herman, SJ McConnell, N Rothstein, RH Yager. 1972. Survey of wild mammals in a Chesapeake Bay area for selected zoonoses. J Wildl Dis 8, 119-126.

Aragón-Martínez A, LD Olivera-Gómez, D Jiménez-Domínguez. 2014. Seasonal prevalence of antibodies to Leptospira interrogans in Antillean manatees from a landlocked lake in Tabasco, Mexico. $J$ Wildl Dis 50, 505-511.

Baba K, T Kaneda, H Nishimura, H Sato. 2013. Molecular detection of spotted fever Group Rickettsia in feral Raccoons (Procyon lotor) in the Western part of Japan. J Vet Med Sci 75, 195-197.

Becker DJ, DG Streicker, S Altizer. 2015. Linking anthropogenic resources to wildlife-pathogen dynamics: a review and meta-analysis. Ecol lett 18, 483-495.

Beltrán-Beck B, FJ García, C Gortázar. 2012. Raccoons in Europe: disease hazards due to the estabilishment of an invasive species. Eur J Wildl Res 58, 5-15.

Bigler WJ, JH Jenkins, PM Cumbie, GL Hoff, EC Prather. 1975. Wildlife and environmental health: raccoons as indicators of zoonoses and pollutants in southeastern United States. J Am Vet Med Assoc 167, 592-597.

Boeer WJ, RP Crawford, RJ Hidalgo, RM Robinson. 1980. Small mammals and white-tailed deer as possible reservoir hosts of Brucella abortus in Texas. $J$ Wildl Dis 16, 19-24.

Compton JA, JA Baney, SC Donaldson, BA Houser, GJ San-Julian, RH Yahner, W Chmielecki, S Reynolds, BM Jayarao. 2008. Salmonella infections in the common raccoon (Procyon lotor) in Western Pennsylvania. J Clin Microbiol 46, 3084-3086.

Contreras-Moreno FM, K de-la-Cruz-Felix, J Bello-Gutiérrez. 2012. Uso patrones de cacería y preferencias de presas en dos sitios del parque estatal La Sierra, Tabasco, México. Etnobiología 10, 1-9.

Falkenhorst G, J Simonsen, TH Ceper, W van Pelt, H de Valk, M Sadkowska-Todys, L Zota, M Kuusi, C Jernberg, MC Rota, YT van Duynhoven, PF Teunis, KA Krogfelt, K Mølbak. 2012. Serological cross-sectional studies on salmonella incidence in eight European countries: no correlation with incidence of reported cases. BMC Public Health 12, 523.

Fukata T, F Naito, N Yoshida, T Yamaguchi, Y Mizumura, K Hirai 2002. Incidence of Salmonella infection in healthy dogs in Gifu Prefecture, Japan. J Vet Med Sci/Japan Soc Vet Sci 64, 1079-1080.

Funk SM, CV Fiorello. 2001. The role of diseases in carnivore ecology and conservation. In: Gittleman JL, Funk SM, MacDonald D, Wayne RW (eds). Carnivore conservation. Cambridge University Press, Cambridge, UK, Pp 443-466.

Gannon WL, RS Sikes, Animal Care and Use Committee of the American Society of Mammalogists. 2007. Guidelines of the American Society Mammalogists for the Use of Wild Mammals in Research. J Mammal 88, 809-823.

Gompper ME. 1995. Nasua narica. Mamm Species 487, 1-10.

Hall AJ, EK Saito. 2008. Avian wildlife mortality events due to salmonellosis in the United States, 1985-2004. J Wildl Dis 44, 585-593.

Hoelzer K, AM Switt, M Wiedmann. 2011. Animal contact as a source of human non-typhoidal salmonellosis. Vet Res 42, 34.

Issak-Delgado AB. 2014. Evaluación de ectoparásitos en una población de coatis (Nasua narica) y mapaches (Procyon lotor) del ParqueMuseo La venta, en Villahermosa, Tabasco, durante el verano del 
2010 al invierno del 2012. Tesis, Facultad de Medicina Veterinaria y Zootecnia, Universidad Nacional Autónoma de México, México.

Jardine C, RJ Reid-Smith, N Janecko, M Allan, SA McEwen. 2011. Salmonella in Raccoons (Procyon lotor) in Southern Ontario, Canada. J Wildl Dis 47, 344-351.

Junge RE, K Bauman, M King, ME Gompper. 2007. A serologic assessment of exposure to viral pathogens and Leptospira in an urban raccoon (Procyon lotor) population inhabiting a large zoological park. $J$ Zoo Wildl Med 38, 18-26.

Lotze JH, S Anderson. 1979. Procyon lotor. Mamm Species 119, 1-8.

Morse EV, DA Midla, KR Kazacos. 1983. Raccoons (Procyon lotor) as carriers of Salmonella. J Environ Sci Health A Tox Hazard Subst Environ Eng 18, 541-560.

Murray DL, CA Kapke, JF Evermann, TK Fuller. 1999. Infectious disease and the conservation of free-ranging large carnivores. Anim Conserv 2, 241-254.

Oliveira-Filho EF, JJW Pinheiro, MMA Souza, VLA Santana, JCR Silva, RA Mota, FB Sá. 2012. Serologic survey of brucellosis in captive neotropical wild carnivores in Northeast Brazil. J Zoo Wildl Med 43, 384-387.

Olopoenia LA, AL King. 2000. Widal agglutination test - 100 years later: still plagued by controversy. Postgrad Med J 76, 80-84.

Packer C, S Altizer, M Appel, E Brown, J Martenson, SJ O’Brien, M Roelke-Parker, R Hofmann-Lehmann, H Lutz. 1999. Viruses of the Serengeti: Patterns of infection and mortality in African lions. J Anim Ecol 68, 1161-1178.
Schnurrenberger PR, RP Brown, EP Hill, CM Scanian, JA Altiere, JT Wyoff. 1985. Brucella abortus in wildlife on selected cattle farms in Alabama. J Wildl Dis 21, 132-136.

Silva-Hidalgo G, HS Lopez-Moreno, VF Ortiz-Navarrete, F JuarezBarranco, M Lopez-Valenzuela. 2012. Fecal excretion of Salmonella Albany, its isolation in the diet and health repercussion on an ocelot (Leopardus pardalis) in captivity. Vet Mex 43, 59-69.

Sørensen KK, T Mørk, OG Sigurðardóttir, K Åsbakk, J Åkerstedt, B Bergsjø, E Fuglei. 2005. Acute toxoplasmosis in three wild arctic foxes (Alopex lagopus) from Svalbard; one with co-infections of Salmonella Enteritidis PT1 and Yersinia pseudotuberculosis serotype 2b. Res Vet Sci 78, 161-167.

Thorns CJ, MG Sojka, IM McLaren, M Dibb-Fuller. 1992. Characterisation of monoclonal antibodies against a fimbrial structure of Salmonella enteritidis and certain other serogroup D salmonellae and their application as serotyping reagents. Res Vet Sci 53, 300-308.

Verma AK, Sinha DK, BR Singh. 2008. Micro-Agglutination Test (MAT) based sero-epidemiological study of salmonellosis in dogs. J Immunol Immunopathol 10, 29-35.

Wright AN, ME Gompper. 2005. Altered parasite assemblages in raccoons in response to manipulated resource availability. Oecologia 144, 148-156.

Zavala-Castro JE, JE Zavala-Velázquez, DH Walker, EE Ruíz-Arcilla, H Laviada-Molina, JP Olano, JA Ruiz-Sosa, MA Small, KR DzulRosado. 2006. Fatal human infection with Rickettsia rickettsii, Yucatan, Mexico. Emerg Infect Dis 12, 672-674. 